\title{
TYPES, FUNCTIONS, AND MORPHOLOGICAL PROCESS OF REDUPLICATION IN SUMBAWA BESAR DIALECT
}

\author{
Ismiati \\ Faculty of Teacher Training and Education, Cordova University, Indonesia \\ Corresponding Author Email: ismiatisumarlin08@gmail.com
}

\begin{tabular}{l}
\hline \hline Article Info \\
\hline Article History \\
Received: September 2021 \\
Revised: October 2021 \\
Published: October 2021 \\
\hline Keywords \\
Reduplication; \\
Sumbawa Besar Dialect;
\end{tabular}

\begin{abstract}
The study discusses the types, functions, and morphological processes of Reduplication in the Sumbawa Besar dialect. Data was taken from recorded conversation, which naturally occurred among the native speakers of Sumbawa Besar Dialect. The native were also interviewed to gain deeply information. Finding of this study describes some types of Reduplication in Sumbawa Besar Dialect namely full Reduplication, partial Reduplication, and reduplication variation of phoneme. In full Reduplication, the word is fully repeated without any additional morpheme or phoneme to the base word. For example, the base word 'lao' (slow) is fully reduplicated becomes 'lao-lao' (slowly). Partial Reduplication is partly the repetition of the base word. For example, 'Barema' (together) is the base form that is reduplicated by repeating the last phoneme to become 'Barema-rema'. 'Barema' is the base and 'rema' is its phoneme which is repeated to form Reduplication. Reduplication variation of phoneme is the type of Reduplication which combines two different word classes and meaning to create meaningful Reduplication. As example, 'sedo-gaso' (supplies). 'sedo' is the first base word and the second word is 'gaso'. Those are combined to create Reduplication becomes 'sedo-gaso' (supplies). Function of Reduplication in Sumbawa Besar Dialect was to change word classes as verb is changed into noun and change singular form to plural form of the noun. In example, 'Mangan' (eat) is the word class of verb which is changed into the word class of noun 'Mangan'- 'Mangan' (a picnic) in its Reduplication. In another example, the word Anak (a child) is the singular form of noun is changed into plural form Anak-dadi (children) in its Reduplication.
\end{abstract}

How to cite: Ismiati. (2021). Types, Functions, and Morphological Process of Reduplication in Sumbawa Besar Dialect, JOLLT Journal of Languages and Language Teaching, 9(4), pp. 471-479. DOI: https://doi.org/10.33394/jollt.v\%vi\%i.4257

\section{INTRODUCTION}

Samawa Language is a vernacular language which is mostly spoken by Sumbawa ethnic in Sumbawa Island. Mahsun (1994) found that Sumbawanese have four dialects: Jereweh, Taliwang, Tongo, and Sumbawa Besar. Sumbawa Besar dialect has been agreed as standard language for all of Sumbawanese. Each of the local dialects of Sumbawa language has its own characteristics, forms, function, and meanings that are different from one another. For example the form and function of Reduplication of one dialect must be different from another dialect.

Aziz and Nolikasari (2020) assert that Reduplication is the process of word formation through which words or morphemes are repeated. Alwi (2003) states that repetition is the process of word reduction. A repetitive word goes through repetition as a whole or partial process or followed by sound changing. According to Kosasih, (2008) in Susanto (2008), there are two types of Reduplication; Full Reduplication and Partial Reduplication. Full Reduplication describes that the basic word is repeated completely without any variation of phoneme or morpheme. In Partial Reduplication, the Reduplication happens on the part of the basic word. The basic word is not completely reduplicated but partially. Hudiyono and 
Noviansah (2018) found some types of Reduplication in Dayak Tunjung Language namely whole Reduplication, partial Reduplication, and Reduplication with phoneme change.

Reduplication in each language has its own function. Alsamadani and Taibah (2019) describe that the reduplication Reduplication function in Palembang is to generate a wide variety of semantics functions such as pluralization, iteration, distribution, and nominalization. Then, Samawa language is one of the languages which has variety of reduplications. Kamus Bahasa Sumbawa (1982) encoded that Reduplication in Sumbawanesse is generally clasified to full Reduplication. The form of its Reduplication and meaning are far different from its basic from like bale "house" become bale-bale "houses". However, in some case the meaning of its Reduplication can be different from its basic from like "pidan" (when) become "pidan-pidan" (whenever).

This research intents to analyze the types, functions, and morphological process of Reduplication in the Sumbawa language, particularly in Sumbawa Besar Dialect. Literatures on Sumbawa language is still lack in numbers or not easily found in library. Hariyani, et al (2018) found that Sumbawa was categorized as under resources language where there is the only small number of books written and studies in the pieces of literature published to date. Therefore, scientific study on Samawa language needs to be conducted as additional kinds of literature for linguistics study and use to enrich the wealth of cultural treasures of Indonesia.

\section{RESEARCH METHOD}

This study is categorized as descriptive study which applies qualitative approach. Data was taken through several steps. First, the researchers recorded and noted the conversations which naturally occurred in the domain of family and neighbourhood. Then, all the words that related to Reduplication were noted, listed, and verified through interview with the native of Sumbawa Besar dialect as the informants. Next, identified the types, meanings, morphological process and the functions of Reduplication.

\section{RESEARCH FINDINGS AND DISCUSSION \\ Research Findings \\ Types of Reduplication}

Reduplication in Sumbawa Besar Dialect is presented in three types namely full Reduplication, partial Reduplication, and reduplication variation of phoneme as presented in the following tables.

Table 1

Full Reduplication

\begin{tabular}{cllll}
\hline NO & \multicolumn{1}{c}{ Base word } & \multicolumn{1}{c}{ Meaning } & \multicolumn{1}{c}{ Reduplication } & Meaning \\
\hline 1 & Balong & Good & Balong-balong & Good \\
\hline 2 & Pidan & When & Pidan-pidan & Whenever \\
\hline 3 & Senang & Slow & Senang-senang & Slowly \\
\hline 4 & Angan & Imagine & Angan-angan & Imagination \\
\hline 5 & Mangan & Eat & Mangan-mangan & picnic \\
\hline 6 & Lao & Slow & Lao-lao & Slow \\
\hline 7 & Boat & Job & Boat-boat & Jobs \\
\hline 8 & Kau & You & Kau-kau & You \\
\hline
\end{tabular}

Data in table 1 shows that full Reduplication in Sumbawa Besar Dialect is formed by fully repeating the base word. In example, 'balong' is the base word which is changed into its Reduplication becomes 'balong-balong'. 
Table 2

Partial Reduplication

\begin{tabular}{cllll}
\hline NO & \multicolumn{1}{c}{ Base word } & \multicolumn{1}{c}{ Meaning } & \multicolumn{1}{c}{ Reduplication } & \multicolumn{1}{c}{ Meaning } \\
\hline 1 & Balangan & Walk & Balangan-langan & Window shop \\
\hline 2 & Barema & Together & Barema-rema & Together \\
\hline 3 & Tunung & Sleep & Tatunung-tunung & Always sleep \\
\hline 4 & Tokal & Sit & Tatokal-tokal & Always sit \\
\hline 5 & Manang & Stand & Tamanang-manang & Always stand \\
\hline 6 & Bakerek & Little by little & Bakerek-kerek & Little by little \\
\hline 7 & Kemes & Smile & Bakemes-mes & Smile \\
\hline 8 & Le & Late & Basngele-ngele & Too late \\
\hline 9 & Langan & Unexpected & Salangan-langan & Unexpected \\
\hline 10 & Rea & Big & Sarea-rea & All \\
\hline 11 & Sai & One & Basai-sai & United \\
\hline 12 & Batungil & Batungil-tungil & Batungil-tungil & Close \\
\hline 14 & Batari & Wait & Batari-tari & Wait \\
\hline 15 & Tangame & Chew & Tangame-ngame & Always chew \\
\hline 16 & Meloe & How much & Meloe-loe & How much \\
\hline 17 & Bamudi & Later & Bamudi-mudi & \\
\hline
\end{tabular}

Table 2 describes partial Reduplication. It is formed by repeating part of the base form. in example, the base form 'balangan' is changed into its Reduplication becomes 'balangan-langan' in which its part phoneme 'langan' is repeated.

Table 3

Reduplication Variation of Phoneme

\begin{tabular}{cllll}
\hline NO & Base Words & \multicolumn{1}{c}{ Meaning } & \multicolumn{1}{c}{ Reduplication } & Meaning \\
\hline 1 & Senap & Fresh & Senap-semu & Fresh \\
\hline 2 & Sipat & Behavior & Sipat-sato & Behavior \\
\hline 3 & Roro & Rubbish & Roro-rokat & Crumb \\
\hline 4 & Sedo & Sedo-gaso & Sedo-gaso & Help each other \\
\hline 5 & Sakiki & Help & Sakiki-sakoko & Crazy \\
\hline 6 & Gila & Crazy & Gila-ganta & Very slim \\
\hline 7 & Kerong & Slim & Kerong-kanyenyeng & Talkative \\
\hline 8 & Ngote & Talkative & Ngote-ngamin & Peaceful \\
\hline 9 & Riam & Peaceful & Riam-remo & Hectic \\
\hline 10 & Rame & Rame-ramia & Rame-ramia & Complement \\
\hline 11 & Daru & Complement & Daru-reka & Steal \\
\hline 12 & Nyoro & Steal & Nyoro-nyangko &
\end{tabular}

Table 3 shows reduplication variation of phoneme which is formed by combining two different morpheme or phoneme in example, the base word 'senap' is attached to another base 'semu' becomes senap-semu' to form the reduplication variation of phoneme

\section{Discussion}

\section{Types and Morphological Process of Reduplication}

According to Chaer (2003:12), Reduplication is a morphological process of repeating the basic form totally, partially or the exchange of sound Based on the basic form of word. The types of Reduplication in Sumbawa Besar dialect is described as follows. 


\section{Full Reduplication}

Full Reduplication refers to repetition of the whole words. Data of this study describes that the basic words in Sumbawa Besar dialect is fully repeated without adding morpheme or phoneme to the basic word. As stated by Susanto (2008) that in full Reduplication, the basic word is repeated completely without any variation of phoneme or morpheme. Full reduplications in Sumbawanese language, in dialect of Sumbawa Besar are presented as follows:
1) $\underline{\text { Lao }}$ Slow-ADJ (Base Form)
2) Mangan Eat-V (Base Form)
3) Angan Remember-V (base form)
4) Boat Job-N (base form)
5) Balong Good-ADJ (base form)
6) Ode Small-ADJ (base form)
7) $\mathrm{Tau}$ A person-N (base form)
8) Senang Slow-ADJ (base form)
9) Pidan

When- Qustion word (base form)

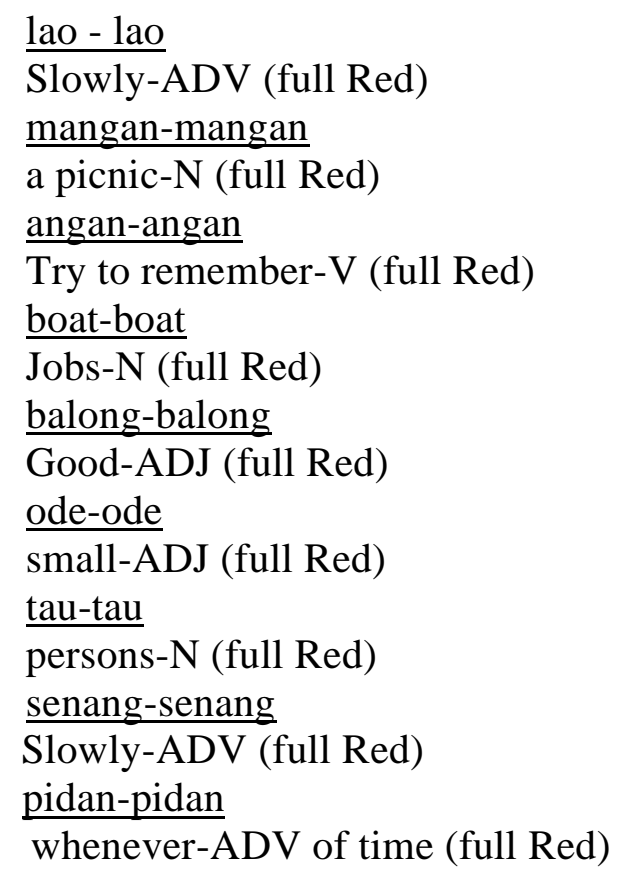

From the words list above, it can be explained that all words are classified as full Reduplication of Sumbawanese language, particularly in the dialect of Sumbawa Besar. It is called as full Reduplication because all of the base form of the word is fully repeated without any additional morpheme or phoneme to the base word. For example, the base word 'lao' which means slow is fully reduplicated becomes 'lao-lao' meant slowly. Full Reduplication (full red) 'mangan-mangan' (a picnic) was formed from the base word 'mangan' (eat). The base form of the third word in the list is 'angan' means remember is changed to the form of Reduplication becomes 'angan-angan' which means asking someone to remember. 'boat' is the base form which is repeated becomes 'boat-boat' which meant job.

To form full Reduplication in Sumbawa Besar dialect, the base words result another word classes. For example, the base form 'lao' (slow) is a word class of adjective results full reduplication ' lao-lao' (slowly) as part of adverb word classes. The base form 'mangan' (eat) is a word class of verb. Reduplication form the base word 'mangan' is 'mangan-mangan' (a picnic) is part of Noun word class.

In another case, the form of fully Reduplication in Sumbawa dialect has the same word class with its base word. As example, the base word 'ode' (small) is adjective word class. Reduplication of the base word 'ode' is 'ode-ode' (small) is also a word class of adjective. The base word 'boat' (job) has the same word class with its reduplication 'boatboat' (jobs) as part of Noun classes.

In addition, it can be described that Full Reduplication in Sumbawa Dialect shows different word classes and meaning from its base word. In example. Mangan'is a base word which forms full reduplication becomes 'mangan-mangan'. The two morphemes function as different word classes and have different meaning. 'mangan' is part of verb word class 
which means 'eat' and 'mangan-mangan' is a word class of noun which has meaning 'a picnic'. The base form' pidan' is a type of question word which has meaning 'when' and its reduplication 'pidan-pidan' is the word class of adverb of time which means 'whenever'. The base form 'senang' is a word class of adjective which means 'slow' is changed to full Reduplication becomes 'senang-senang' as part of adverb word class which means 'slowly.

Finding of this research agrees to the finding of study which was conducted by researchers team from Udayana University, Structure dan KamusBahasa Sumbawa (1982) which encoded that Reduplication in Sumbawanesse generally is included to full Reduplication. The form of its Reduplication and meaning are far different from its basic from like "bale "house" become bale-bale "houses". However, in some case the meaning of its Reduplication can be different from its basic from like "pidan" (when) become "pidanpidan" (whenever).

\section{Partial Reduplication}

Susanto (2008) claimed that partial Reduplication happens on the part of the basic word. In other word, the base word is not completely reduplicated. Susanto introduced two forms of partial Reduplication; single Reduplication and complex Reduplication. In Sumbawa language, single Reduplication as it appears in Indonesian language Laki' becomes 'Lelaki' was not found. There only found complex reduplication which means that to form such Reduplication, the base word cannot stand by itself but it is completed by its part. Partial reduplications in Sumbawa Besar dialect are presented below:
1) Barema
Barema- rema
Based form partial- RED
together-ADV of manner
2) Bakemes
Bakemes - mes
Based form partial- RED
Smile-V
3) Bakerek
Bakerek- kerek
Based form partial-RED
4) Balangan
Balangan - langan
Based form
partial-RED
Little by little-ADV
5) Batungil
Based form
Batungil- tungil
6) Batari
partial-RED
Walk-V
Based form
Batari - tari
Near-ADJ
7) Tanyangkok
partial-RED
Waiting for- $\mathrm{V}$
Based form
tanyangkuk- nyangkok
partial-RED
Lazy-ADJ
8) Sarea
sarea - rea
Based form
partial-RED
All-ADV of quantity

In the case of partial Reduplication in Sumbawa Besar dialect, the base word is partially repeated to form partial Reduplication. The last part of the base word is repeated. In other word, the last or the two last phoneme or syllable of the base word is commonly repeated to form the partial Reduplication (partial-RED). For example, the base form 'barema' (together) consists of three syllables ' $b a$ ', ' $r e$ ' and ' $m a$ ' or consist of two bound morphemes, prefix ' $b a$ ' and suffix 'rema'. To form partial Reduplication of the base word' barema', the two last syllables ' $r e$ ' and ' $m a$ ' are combined and repeated or the last bound morpheme 'rema' is repeated. The first syllable or prefix 'ba' of the base form is not repeated. Another example is described from the base word 'balangan' which consists of three syllables; ' $b a$ ', 'la', 'ngan' or three bound morphemes; 'prefix ' $b a$ ', and suffix 'langan'. To form partial Reduplication from the base word 'balangan', the two last syllables ' $l a$ ' and 'ngan' are combined and repeated becomes 'balangan-langan'. 
Partial Reduplication in Sumbawa Besar dialect has the same meaning and same word class with its base form. It can be seen from this example, the base form 'bekemes' and its reduplication 'bekemes-mes' are part of adjective word class and both mean smile in English. The base form 'batari' has the same word clss and meaning with its reduplication 'batari-tari'. Both are part of verb word class and mean 'waiting for' in English. Another example is described from the partial reduplication 'sarea-rea' and its base form 'sarea' are classified as adverb of quantity which mean 'all' in English.

\section{Reduplication Variation of Phoneme}

Susanto (2008) states that Reduplication variation of phoneme is Reduplication in which the basic form of word is different from its Reduplication. This type of Reduplication is found in Sumbawa dialect. It shows irregular process of forming the Reduplication. it means that the form of Reduplication is different from its basic word. The explanation of Reduplication of phoneme pariation in Sumbawa Besar dialect is presented bellow:
1) Sedo
Sedo-gaso
Base Form
Variation-Red
supplies-N
2) Gila
Gila-ganta
Base Form
Variation-RED
crazy-ADJ
3) Kaputung
kaputung-Kapua
Base Form
Variation Red
In rush-ADV of manner
4) Daru
Daru- reka
Base Form
Variation-Red
Ingredients
5) Riam
riam-remo
Base Form
Variation-Red
Peaceful
6) Rame
rame-ramia
Base Form
Variation Red
Crowded
7) Roro
Base Form
roro-rokat
8) Senap
Variation Red
Useless
Base Form
senap-Semu
9) Mangan
Variation Red
Fresh
Base Form
mangan-ngenta
Variation Red
Eat

The data above are categorized as Reduplication of phoneme or morpheme variation. This type of Reduplication describes the variation of the base form which is resulted by adding another phoneme or morpheme which has different form with its base form. In another word, The Reduplication of variation is formed by combining the base form and another form of morpheme or phoneme. In example, the base form 'Sedo' (supplies) is the base form of the word forms its Reduplication by adding a new morpheme which has different form from its basic word. 'sedo (supplies)' becomes 'sedo-gaso (supplies)'. 'gaso' (supplies) is another morpheme which is attached to the base form 'sedo (supplies)' to form Reduplication of variation 'sedo-gaso (supplies)'. Another example of this case can be describes from the base word 'gila' (crazy) which forms its Reduplication by adding a new morpheme 'ganta' (crazy) becomes reduplication of phoneme variation 'gila-ganta' (crazy).

In terms of the meaning and word classes, this type of Reduplication shows that the base word has the same meaning and word class with its reduplication form. In example, the base form 'kaputung' and its reduplication 'kaputung kapua' are part of adverb of manner word class and both mean in rush or in a hurry in English. 'Daru reka' as Reduplication of base form daru' in Sumbawa besar dialect mean 'ingredient in English and classified as the word class of noun. 
In another case, this type of Reduplication may have different meaning from its base word. As example, the base word 'roro' means rubbish and its reduplication 'roro-rokat' means useless.

\section{Function of Reduplication}

Functions of reduplications in Sumbawa dialect are presented as follows:

Change the word classes

Reduplication in Sumbawa Besar dialect can change the word classes as the Change the adjective into adverb

\section{ADJ}

\section{Senang (Slow) \\ 2. Lao} (Slow)

3. Gila (crazy)

4. kameri
ADVERB (in reduplication case) senang-senang Base Form + full-RED (slowly)

lao-lao

Base Form + part.RED (slowly) gila-ganta

Base Form + part.RED (folly)

kameri-kemore

From the example above, it can be explained that function of Reduplication in Sumbawanese, the dialect of Sumbawa Besar is to change the word classes. As Collins, at, el (2001) in Rubino Carl (2005) stated that Reduplication can be used to form new words. The above data describes that the word class of adjective is changed into another form of word classes. In example, (1) the free morpheme 'senang' (slow) is part of adjective word class which is changed into reduplication form becomes 'senang-senang' (slowly) which is known as adverb in Sumbawa Besar dialect. The word 'Lawo' (slow) (2) is adjective, then forms its Reduplication becomes 'lao-lao' (carefully) which is part of adverb. (3) gila (crazy) is adjective is reduplicated becomes 'gila-ganta' (crazily) as adverb of manner. The word 'kameri' (happy) is adjective word class which is changed into adverb 'kameri-kamore' (happily).

\section{Change singular to plural form of nouns}

Another function of Reduplication in Sumbawa Besar Dialect can change the singular form into plural form of noun as the following examples:
Singular
Plural
1. Tode
tode-tode
(a kid)
Base Form + full-RED (kids)
2. Anak anak-dadi
(a child)
Base Form + Phoneme (children)
3. Tau
tau-tau
(a person)
4. Bale
Base Form + full-RED (people)
bale-bale
(a house)
Base Form + full-RED (houses)

The above data shows the change of singular nouns become plural form. As by Hardy and Montier (1988) in Rubino Carl (2005) pointed that function of Reduplication is to form plurality. This data above shows the plurality of Reduplication in Sumbawa dialect. point (1) explains that the noun 'tode' (a kid) refers to an indefinite kid which then reduplicated to plural form becomes 'tode-tode' which refers to more than one kids. The word 'anak' is singular form of a child and its plural form is 'anak-dadi' (children). Point (3) describes the word 'tau' (a person) as the singular form of its plurality 'tau-tau' (people). The last is the word 'bale' (a house) is singular noun of its plural form 'bale-bale' (houses). 


\section{CONCLUSION}

Finding of this study describes that the types of Reduplication is Sumbawa Besar Dialect is divided into full Reduplication, partial Reduplication, and reduplication variation of phoneme. In full Reduplication, the word is fully repeated without any additional morpheme or phoneme to the base word. For example, the base word 'lao' (slow) is fully reduplicated becomes 'lao-lao' (slowly). To form the full Reduplication, the word classes and meaning or the base word and its Reduplication can be different or the same. Partial Reduplication is partly repetition of the base word. 'Barema' is the base form which is reduplicated by repeating the last phoneme becomes 'Barema-rema'. In the case of this Reduplication, the word classes and meaning of the base form are the same with its Reduplication. Reduplication variation of phoneme is the type of Reduplication which describes different form with its base word. As example, 'sedo-gaso' (supplies) is the Reduplication of base form 'sedo' (supplies). This type of Reduplication shows the same meaning and word classes with its base form. In another case, this type of Reduplication may have different meaning from its base word. Function of Reduplication in Sumbawa Besar Dialect were to change word classes as adjective into adverb and change singular form to plural form of noun.

\section{ACKNOWLEDGEMENT}

I would like to express my gratitude to all people who support within the whole process of this study.

\section{REFERENCES}

Aziz, Z. \& Nolikasari, V (2020). Reduplication as a Word-Formation Process in the Jamee Language: A Variety of Minang Spoken in South Aceh. Journal Studies in English

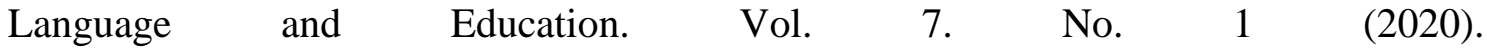
DOI:https://doi.org/10.24815/siele.v7i1.15693.

Alsamadani, M., \& Taibah, S (2019). Types and Function of Reduplication in Palembang. Journal of the Southest Asian Linguistics Society 12,1 (2019): 113-142. DOI:http://hdl.handle.net/10524/52447.

Alwi, H et.al. (2003) Tata Bahasa Baku Bahasa Indonesia. Jakarta: Balai Pustaka.

Dalrymple, M (2011). Plural Semantics, Reduplication, and Numeral Modification in Indonesia. Journal of Semantics 29(2). DOI: 10.1093/jos/ffr015.

Depdikbud (1989)..Kamus Sumbawa Indonesia. Jakarta: Balai Pustaka.

Hudiyono, Y \& Noviansah, A (2018). The Morphological Processes of Dayak Tunjung Language in Desa Mura Jawaq Kecamatan Mook manaar Bulatn Kutai Barat Regency. Proceeding of Educational Sciences International Conference (ESIC 2019). http://doi.org/10.2991/esic-18.2019.19.

Hariyanti T, Aida S, Kameda H (2018). Samawa language; part of Speech Tagset and Tagged Corpus for NLP Resources IOP Conf. Series: Journal of Physics: doi: 10.1088/17426596/1061/1/012007

Mangga, S (2020). Morphological Analysis of Manggarai Language. Journal of Linguistics and Education, vol. 10, no. 2. Pp. 124-135, Oct. 2020. http://doi.org/10.14710/parole.v10i2.124-135.

Mahsun (1994) Penelitian Dialek Geografi Bahasa Sumbawa Yogyakarta: Tesis S3 Universitas Gadjah Mada. 
Nursaly, B. R. (2019). Adjective Reduplication of Sasak Dialect Meno-Mene in Karang Bagu. Voices of English Language Education Society. Vol. 3. No. 2; October 2019. p. 82-91. DOI: 10.29408/veles.v3i2.1535.g922.

Otun, J. O. (2021). The Study of Reduplication and Retriplication in the Yoruba Language. Journal of Language and Literature. Vol. 21. No.1. DOI:https://doi.org/10.24071/joll.v21i1.2933.

Ratu, D M \& Maru, M G (2017). Reduplication of Mongondow Language. A Journal of Culture, English Language, Teaching \& Literature. Vol. 17. No. 2. Desember 2017. https://doi.org/10.24167/celt.v17i2;

Saranza, R (2014). Morphophonemic Variation among Kinamayo Dialects: A Case Study. Journal of Literature, Philosophy and Reigion. Vol. 6. Doi: http://dx.doi.org/10.7718/iamure.ijlpr.v6i1.852.2

Susanto (2008). The Nature of Reduplication in Sumbawanesse: IKIP Mataram 